\title{
Analysis on Admissibility of DNA Evidence in Malaysian Syariah Courts
}

\author{
Ahmad Azam Mohd. Shariff ${ }^{1}$ \\ Alias Azhar ${ }^{2}$ \\ Ramalinggam Rajamanickam ${ }^{1}$ \\ Nazura Abdul Manap ${ }^{1}$ \\ Safinaz Mohd Hussein ${ }^{1}$ \\ Muhamad Helmi Md. Said ${ }^{1}$ \\ Asma Hakimah Ab Halim ${ }^{1}$ \\ Ruzian Markom ${ }^{1}$ \\ ${ }^{1}$ Faculty of Law, UKM, Malaysia \\ ${ }^{2}$ School of Law, UUM, Malaysia
}

Doi: $10.36941 / a j i s-2019-0050$

\section{Abstract}

Qarinah is a kind of evidence which could be tendered in syariah courts' during trials. Syariah scholars and academicians have long acknowledged and recognized the unique and important role played by qarinah in syariah court proceedings. General acceptance, relevancy and admissibility of qarinah evidence have become the catalyst for admissibility on DNA evidence within the syariah legal fraternity. Amidst the relevancy and admissibility of DNA evidence under the current syariah legal provisions, ongoing debates on its application are brewing among contemporary academicians. Indeed, these debates stems from current legal provisions which are still underdeveloped. This article examines the admissibility of qarinah as well as DNA evidence in the light of the relevant provisions under the Malaysian Syariah Court Evidence Enactment. The research on which this article is based is qualitative and doctrinal in nature. All materials and information are analyzed through methodologies of content analysis and critical analysis. The article then looks into lacunas and gaps in the Malaysian Syariah Court Evidence Enactments as well as the Syariah Criminal Procedures Enactments and suggests on how to improve them.

Keyword: qarinah, DNA evidence, hudud cases, qisas cases, ta'zir cases, proof, syariah trials

\section{Introduction}

Admissibility of forensic evidence is not alien to the modern legal world. Forensic evidence is often tendered in court trials in countries which enforce man-made law. The United Kingdom and the United States of America, to name a few, are exemplary countries which have demonstrated significant developments in the area of forensic evidence.

Malaysia adopts a dual legal system of civil and syariah. In Malaysia, positive developments and evolutions could be witnessed too in the area of forensic science. Inevitably, such developments and evolutions have triggered intriguing developments and applications of forensic 
evidence in civil and criminal trials in the Malaysian civil courts. One of the well-known areas of forensic evidence which has witnessed positive developments in the Malaysian civil courts is deoxyribonucleic acid evidence which is well known as DNA evidence. Indeed, DNA testing, which is one of the achievements of the development of science and technology, is now being tendered as evidence in the Malaysian civil courts as corroborative evidence. Its corroborative evidence and value are presented in trials via the tendering of physical exhibits, as well as through the testimony of expert witnesses. Although the Malaysian development on DNA evidence is not actually parallel to that of their foreign counterparts, it is nonetheless progressing.

While the basic issues of relevancy and admissibility of DNA evidence at the Malaysian civil courts are somewhat settled amidst further refinement on the intricacies of its application, the basic issues on the relevancy and admissibility of DNA evidence at the Malaysian syariah courts remain very much open and debatable. It is pertinent to note that while relevancy and admissibility of qarinah and DNA evidence have been more or less accepted by the related syariah legal provisions as well as by the Malaysian syariah legal fraternity (amidst some dissenting views and resistance from some), the related basic legal principles regarding both are very much under-developed, fragile and in need of further refinement (Azam, 2012).

Hence this article focusses on the issue of relevancy and admissibility of DNA evidence in the Malaysian syariah courts. In doing so, the article discusses on the relevancy and admissibility qarinah in the light of relevant legal provisions under the Malaysian Syariah Court Evidence Enactment. Based on such qarinah relevancy and admissibility, the article then points out the relevancy and admissibility of DNA evidence in the Malaysian syariah courts as agreed upon by many contemporary academicians. However, the article acknowledges the need for further refinement of legal principles pertaining to qarinah evidence. It eventually identifies the lacunas and gaps in the current provisions in the Malaysian Syariah Court Evidence Enactments and Syariah Criminal Procedure Enactments suggest ways on improving the current legal provisions in ensuring smoother application of principles on qarinah and DNA evidence.

\section{Some Terminologies Used in This Analysis}

To add clarity to the ensuing discussion and debate, the article would like to explain on some of the terminologies used throughout the article:

- Allah- God believed by in oneness and singularity all Muslims.

- the Quran- The words of Allah containing the way of life as firmly believed by the Muslims. Its adjective is Quranic.

- the Sunnah- The guidance taken from the Holy Prophet in forms of his words, approvals or disapprovals. It is also known as Hadith.

- hudud- The seven criminal cases which definitions and punishments have been specifically defined and determined by Allah in the Quran and the Sunnah. Hudud cases are adultery, defamation of adultery, drinking wine, theft, robbery, apostacy and waging war against an Islamic government.

- qisas- Criminal cases other than those of hudud cases. Cases that fall under this category would be all types of offences against human's life and body. Crimes such as murder or causing grievous hurt would fall under the category of qisas cases and the definitions as well as punishments for each type of offence have also been specifically defined and determined by Allah in the Quran and the Sunnah.

- ta'zir- Criminal cases which fall out of the ambit of hudud and qisas. Generally speaking, ta'zir offences and punishments are not clearly set out in the Quran or the Sunnah. As such the enactments as well as punishments of such offences are to be determined by the government in administration according to local customs and practices. Normally, ta'zir punishments are lighter than that of hudud and qisas punishments although sometimes it could be just as severe, depend on the seriousness of the crime committed.

- fuqaha'/ulama'- A group of jurists who are experts in syariah/lslamic principles.

- qarinah- A form of evidence or any fact in issue or any relevant fact taken from the 
circumstance of a particular case.

- yaqin- Beyond any doubt. Such quantum of proof needs to be fulfilled by the prosecution at the end of the case before the court decides on whether or not the accused is guilty.

- zan al ghalib/ghalabah al zan- A possibility which is akin to the truth. This quantum of proof needs to be satisfied by a party in a non-criminal case. As such the quantum is higher than that of 'balance of probabilities', a quantum of proof determined in modern contemporary civil cases. Some argues that the said quantum of proof is also set out for the prosecution in conviction of the accused in ta'zir cases.

- syariah courts- Courts administering syariah or Islamic laws.

- qiyafah- A method of proving paternity by way of examining and comparing resemblances and similarities between one's feature over the other.

- li'an- The process of oaths taken by both parties in denial of adultery or one's status of being born out of wedlock.

- nasab- The paternity of a person.

- hadhanah- Custody of a child or children.

- syahadah- An oral testimony of a witness which fulfils all the necessary conditions.

- iqrar- A confession made by an accused in a criminal prosecution.

- qaul qadim- The old Islamic/syariah school of thought.

- qaul jaded-The new Islamic/syariah school of thought.

- 'urf- Common practices which are in tandem with syariah/lslamic principles.

- mal- cases which are non-criminal in nature.

- ra'yu al-khabir- testimony by experts

\section{Research Methodology}

The article is built on a research design which is of legal and qualitative in nature. That being so, the research uses library research as well as interviews as methods of gathering data and information on qarinah and DNA evidence. Such library data and information are gathered from the Quran, Sunnah of the Prophet as well as other sources like books, articles, legal provisions and reported cases. In terms of interviews, this research gathers data and information on qarinah and DNA evidence through semi-structured as well as non-structured interviews (Anwarul Yaqin, 2007) of various experts in the fields of qarinah, DNA evidence as well as syariah legal provisions. This study also uses primary and secondary data.

As far as analysis is concerned, methods of content analysis, critical analysis as well as observations are used. The contents of these data and information, gathered from legal provisions, cases as well as other library sources, are carefully and critically analysed (Ramalinggam Rajamanickam et al., 2015). Often, such content analysis and critical analysis techniques involve authentic and creative process of stating, interpreting and clarifying existing laws on legal issues (Mahdi Zahraa, 1998). On the matter at hand, existing laws and legal issues on qarinah and DNA evidence are critically analysed. Meanwhile, gathered data and information from interviews are also directly analysed, sometimes using observation techniques of analysis. (Anwarul Yaqin, 2007).

\section{Qarinah Evidence: Relevancy and Admissibility in the Eyes of Syariah Evidential Principles}

Qarinah in its literal meaning means signs or things that indicate something (Ahmad Fathi Bahnasi, 1989). Al-Sayyid Sabiq states qarinah as a sign that triggers belief, which could become evidence and forms legal basis (Al-Sayyid Sabiq, 1994). Abdul Karim Zaydan defines qarinah as signs or proof which are circumstantial in nature that could be used as evidence of conviction or denial (Abdul Karim Zaydan, 1998). According to Wahbah al-Zuhayli, qarinah signifies signs connected to hidden or unknown facts. He further explains that such circumstantial signs help to establish and ascertain the truth or falsehood of any disputed fact (Wahbah al Zuhayli, 1989). Clearly syariah evidential principles uphold the relevancy and admissibility of qarinah as evidence and proof in 
syariah mal and criminal cases.

The traditional syariah evidential principles view qarinah evidence as relevant and admissible in mal cases as well as in syariah criminal cases of ta'zir. Some ulama' from the Sunni school of thought, such as Ibn Qayyim, have even stretched out the said relevancy and admissibility to hudud and qisas cases. Such a strong acceptance of qarinah evidence stems out from its strength and accuracy (Azam, 2012).

Such approval is clearly based on a string of authentic Quranic verses. Surah Yusuf, verse 18, reads as follows:

"They stained his shirt with false blood. He said, Nay, but your minds have made up a tale (That may pass) with you. For me patience is most fitting: against what you assert, It is Allah (alone) Whose help can be sought."

In the above verse, the Prophet Yaacob was not fooled by the effort made by the perpetrators when they smeared the blood of a goat on Prophet Yusuf's clothes. He could actually see through the smearing of the false blood as circumstantial signs or qarinah of the perpetrators trying to hide the truth that Prophet Yusuf was still alive and not dead.

In another Quranic verse, Surah Yusuf, verses 25-29, Allah SWT says to the following effect:

\begin{abstract}
"So they both raced each other to the door and she tore his shirt from the back: They both found her lord near the door. She said: What is the (fitting) punishment for one who formed an evil design against Thy wife, but prison or a grievous chastisement? He said: It was she that sought to seduce me from my true self. And one of her household saw this and bore witness, (thus) If it be that his shirt is rent from the front, then is her tale true, and he is a liar. But if it be that his shirt is torn from the back, then she is the liar, and he is telling the truth. So when he saw his shirt that it was torn at the back, Her husband said: Behold! It is a snare of you women. Truly mighty is your snare!"
\end{abstract}

In the second section of Surah Yusuf, it was clear that there were circumstantial signs or qarinah that Zulaikha was the one who was assaulting Yusuf and not the other way round. This was because Yusuf's clothing was torn at the back and not at the front, proving that Yusuf was trying to escape from Zulaikha's assault on him.

Besides the above verses of Surah Yusuf, there were many Hadith or Sunnah of the Prophet SAW which approves qarinah as evidence and proof. One of such examples is when the Prophet SAW used qiyafah, a method of proving nasab or paternity by way of examining and comparing resemblance and similarities between features of one over another. Qiyafah is actually the process of establishing someone's paternity based on qarinah or circumstantial evidence (Mohd Munzil et.al, 2015).

The above syariah evidential principles as well as Quranic verses and Hadith prove that qarinah is relevant and could be tendered as evidence in syariah court trials. The ulama' also agree in saying that only strong qarinah or qarinah al zahirah could be admitted as evidence in syariah proceedings. Majority of the ulama' are in agreement on this (Azam et.al, 2015).

Following the above admissibility of qarinah as evidence by the syariah evidential principles, the Malaysian Syariah Court Evidence enactments have followed suit in providing for the relevancy and admissibility of qarinah or circumstantial evidence in syariah court proceedings. These provisions on such relevancy and admissibility are in tandem with the majority approval by the ulama' such as Ibn Qayyim, Abdul Karim Zaydan, Ahmad Fathi Bahnasi and many others. The effect of these legal provisions from the states' enactments is that qarinah or circumstantial evidence may become relevant, adduced and admitted during syariah mal and criminal proceedings (Ruzman, 1993; Ruzman, 1995; Azam et.al, 2015; Abdul Karim Zaydan, 1997).

In Malaysia, DNA evidence has been widely adduced and admitted in the civil courts. Meanwhile, some syariah court judges have also begun admitting DNA as a type of qarinah in cases of nasab confirmation, in determining issues regarding inheritance and child care or hadhanah. Some syariah courts have even accepted DNA evidences in syariah criminal cases of zina or forbidden intercourse. Among the early syariah cases which admit DNA evidence as qarinah is the Syarie Prosecutor of Sabah v Rosli bin Abdul Japar (23/2 JH 237, 2007). Despite such 
periodic and occasional acceptance by syariah courts and judges, some critics within the syariah legal fraternity remain sceptic of admitting such evidence.

\section{The Malaysian National Fatwa on DNA: Cautious Acceptance in Issues Relating to Child Paternity or Nasab}

The central meeting of the National Council for the $101^{\text {st }}$ Islamic Religious Affairs Fatwa Committee on September 27, 2012 discussed the use of DNA evidence to determine the nasab or child paternity and the duration of the implementation of li'an process in denying the child's nasab. The said central meeting made the following decisions:

Having examined all evidence, arguments and views, the meeting asserted that Islam is very concerned with the question of nasab and when there had been a case that nasab is denied, then the denial was not acceptable except by the method of li'an because li'an had been mentioned by the Quran , al-Sunnah and al-ljma' and is a practice of tauhudiah.

In the said central meeting, it is also explained that Majma' Figh al-Islami who met on $5^{\text {th }}-10^{\text {th }}$ January 2002 (21 - 26 Syawal 1422 Hijrah) had also decided that in order to nullify the nasab of a child, the use of DNA evidence is disallowed in syariah court. Such evidence could however be used in solving other cases such as confusions in accidental child exchanges in hospitals or care centres, babies or children losses due to natural disasters, so on and so forth.

The committee in the central meeting further asserted that the fuqaha' only approved li'an method as a means of nullifying a child's nasab and such process should be promptly carried out. This is because should the denial process in a li'an was not done within the prescribed period, this could nullify the validity of the whole li'an itself.

The said committee also pointed out that referring to the Shafie school of thought, there are the traditional view (qaul qadim) and the new view (qaul jadid) on whether or not the denial process in li'an should be carried out immediately. In qaul qadim, Imam Shafie stipulates that such denial should occur immediately upon the birth of the baby as any delay signifies an acknowledgement and admittance of nasab. However, in qaul jadid, the denial process does not necessarily be performed immediately. According to the new view, since denial is such a significant matter, a denial takes time before a decision is taken as denial of nasab of a child is such a huge and important matter, the whole process may be postponed for up to three days or more should the extra delay is caused by health reasons.

In light of both views, the committee is of the opinion that a person who wishes to deny parentage of his child must be accorded a reasonable period of time before making a decision in avoidance of any possible harm. Accordingly, the committee has decided that a father who wanted to deny the nasab of his child may be accorded a maximum period of time, starting from the date of confirmation of the wife's pregnancy until three (3) days after childbirth. Any effort and forms of denial after such reasonable period will be rejected and the child will be adjudicated as his.

The said committee has also agreed on enforcement of more stringent DNA testing guidelines by the relevant authorities on the issue of denying nasab as DNA evidence is used only to corroborate a claim or denial and should not be used as the main proof.

Although the use of DNA expert evidence is gradually being adopted by the Syariah Court, it is proposed that for cases such as li'an, the Court should be forever cautious in its approach for the benefits of all concerned parties. For instance, DNA evidence should only be allowed in li'an cases if consents are obtained prior to the taking of DNA samples. The court must also ensure that both parties agree to use DNA evidence as proof and as basis for decision in lian cases. Last but not least, the court must ensure that both parties are willing to abide by the decisions made based on the DNA evidence. It is pointed out that although the syariah court is not bound to accept DNA evidence as qarinah, its decision to accept and admit such evidence should be honoured by all (Mohamad Ridzuan bin Zainudin, 2012). According to (Mohd Zaidi, 2015), the acceptance of the DNA evidence as qarinah is dependent on the judge hearing a case. After all expert witnesses as well as exhibits in forms of tested samples are adduced in a syariah court, the judge will then 
decide on whether or not to regard this evidence as relevant. Should they are deemed relevant and do not raise any doubt whatsoever, then the court may admit them.

All in all, it is observed that the Malaysian National Fatwa Council is cautiously accepting DNA evidence in matters regarding child paternity and li'an process.

\section{The Role of DNA in Forensic Science}

DNA is a major component of life. It contains sets of biological or genetic instructions that make up individual individuality. This information is also derived from one generation to another through reproductive development (National Institute of Health, 2016). All life on earth has unique DNA patterns; to make a man a human and a tiger is a tiger. DNA sources of a human or a rabbit or a tree are inherited from their mother or father or known as the parent.

A human will have a complete set of DNA chromosomes obtained by the combination of his mother's and father's. It is 23 pairs of chromosomes with each of them being from parent to absolute number of 46 pairs of chromosomes (American Prosecutors Research Institute, 2015). This set of chromosomes is lined up by millions of information about one's life as a human being. This information is known as genes. Examples of gene are like eye colour or nose shape (American Prosecutors Research Institute, 2015).

DNA could be found in the nucleus. The nucleus is located in the cell that forms the tissue and the organs. DNA could also be in the mitochondria. DNA is located in cells like white blood cells, sperm, vaginal secretion, mucosal fluid, sweat, saliva, ears, hair roots, bones, teeth and organs such as heart and liver, muscles and also skin. Under normal situations, DNA will be extracted from the nucleus and tested to obtain its sequence as comparison data. In cases such as decayed mortal samples or dead cells, extraction and testing of mitochondrial DNA is more appropriate than DNA nucleus.

In Malaysia, DNA testing is carried out by the Malaysian Chemistry Department under the Ministry of Science, Technology \& Innovation (MOSTI). DNA profiling analysis is offered at the Headquarters of Chemistry Department in Petaling Jaya, as well as at its other branches at Kuching, Sarawak and Penang (Mawarni Abdul Rahman, 2015). These labs have been accredited to ASCLD-LAB® ("the American Society of Crime Laboratory Directors/Laboratory Accreditation Board") since 19 October 2005. This section has been accredited and recognized in the field of "Controlled Substances, Toxicology, Biology (Serology and DNA), Firearms/Tool marks and Questioned Documents." The Malaysian Chemistry Department is the tenth laboratory outside the United States to have obtain ASCLD-LAB certification. Such achievement proves that the forensic science service offered by the Malaysian Chemistry Department has met ASCLD-LAB accreditation requirements and is at par with other international forensic laboratories (http://www.kimia.gov.my). This recognition is significant as such accreditation proves its high degree of reliability which is globally recognised and conformity to international standards.

The Malaysian Chemistry Department in their official website of http://www.kimia.gov.my/ outlines the different types of DNA tests conducted by them, among others:

(a) DNA Paternity Test. Paternity Test means a test confirming the relationship between father and child and is usually carried out to ensure or exclude a child's biological father. Paternity test is accurate, fast and reasonably priced with an accuracy of $99.9999 \%$.

(b) Maternity Test. Maternity Test is a DNA test that can give a confirmation related to the mother.

(c) The Ancestry Test is a test that can determine whether a person is a real grandparent to a child.

(d) Sibling Ship Test can determine the relationship between siblings.

(e) Identity Identification. This test aims to determine the identity of an unidentified individual/body.

DNA testing follows a strict controlled process and hence, guarantees result which is of highly reliable. For example, procedure for DNA Paternity Test sampling requires at least $2 \mathrm{ml}$ of blood sample or mouth swab (two samples from each individual) to be taken. Then the blood sample must be stored in the EDTA tube. Samples must be clearly labelled with the name/number and date 
of the sample taken. All samples submitted for analysis must be accompanied by a paternity test application letter and payment for analysis. Samples must be shipped using a courier company or delivered immediately to the laboratory of the Chemistry Department (Mawarni Abdul Rahman, 2015).

\section{Reliability of DNA Evidence}

It has been pointed out earlier that DNA evidence has often been tendered as circumstantial evidence in criminal and non-criminal proceedings at the Malaysian civil courts. However, the same cannot be said regarding its application at the Malaysian syariah courts. Despite the general acceptance of qarinah and DNA evidence within the Malaysian syariah legal fraternity, tendering of such evidence at syariah courts have been sparse and rare in between. The syariah courts are now beginning to be more receptive towards such evidence as witnessed in Syarie Prosecutor of Sabah $v$ Rosli bin Abdul Japar [2007] 23/2 JH 237. Indeed, such positive reception may be influenced by its crucial role in determining the truth in a trial, as well as the potential, strength and reliability of the DNA evidence itself.

DNA evidence plays a vast role in proving an identity of an individual in a court trial (Ramalinggam Ramalinggam et al., 2019). DNA evidence has been known to be tendered in cases involving identification of decayed bodies or mass deaths. DNA evidence has also been tendered in cases involving identification of paternal identity of a child or an abandoned child. Such qarinah has also been used in resolving the issues of nasab of a child for legal inheritance disputes, children being born out of wedlock as well as paternal (or maternal) identification of a child (Mawarni Abdul Rahman, 2015). In addition, DNA evidence has also been tendered in cases such as rape, murder, theft and robbery (Azam, et. al, 2015).

Inspite of the above, DNA evidence is actually capable of playing a much more crucial role in criminal trials. For instance, such evidence is also capable of identifying suspects. It could also be used to acquit them. Furthermore, DNA evidence could also assists investigating officers in identifying victims as well as any other persons who have accessed to the crime scene. In the case of PP v Pathmanabhan Nalliannen \& Ors [2013] $6 \mathrm{MLRH} 19$ (at page 32), SP86, the Director of Forensic Division of the Chemistry Department Petaling Jaya, had extracted DNA from the blood samples taken from the zinc sheets, the cricket bat and swabs from the wall in the farm. On analysis, it was found that the DNA samples matched the samples taken from immediate family members of Sosilawati. In this case, DNA evidence has been used to identify the victim(s) of the murder.

In another case of Public Prosecutor v Haniff Basree bin Abdul Rahim [2004] 3 MLJ 271, DNA samples belonging to an unknown male and the deceased were found on the electrical cord and bra which were used to tie up the deceased. In addition, the hairs recovered from the deceased's bed sheet and comforter matched the DNA profile of the same unknown male. Fingernail clipping of the deceased simultaneously revealed the presence of the DNA profiles of both the accused and the unknown male which proved that the deceased had come into contact with both men. The DNA evidence was successfully adduced and admitted in court, casting doubts on the accused's guilt. It is clear that in the second case, DNA evidence has been adduced and admitted in court which has led to the accused's acquittal.

The main concept of DNA testing is to find the similarities between DNA profiles found on the scene with DNA profiles from known sources. In actual, DNA evidence are often used in proof of paternity in determination of heritage and child custody as well as investigating and determining human remains in mass disaster (Mawarni Abdul Rahman, 2015). In addition, DNA evidence is often used in identifying an individual from a biological sample left on any surface at crime scenes in search of suspects and criminals. If, for instance, the result of a DNA samples matches the result conducted on the sample of the suspect, then the similarities between the two DNA profiles could actually be used corroboratively to support other evidences in proving that the suspect is indeed the crime culprit (Azam et.al, 2015).

The earlier-mentioned potential, strength as well as reliability are generally reflected from the stringent processes of profiling, testing and determination of DNA samples. The strict DNA 
sampling procedures (which results guarantee almost a $100 \%$ result in its reliability) makes DNA evidence a strong and reliable piece of evidence when adduced and admitted by the court corroboratively and in its entirety (Mohd Munzil et.al, 2015; Azam et.al, 2015). The following process illustrates the strict process that a DNA sample has to go through from the moment the investigation officer submits such sample to the Chemistry Department for DNA testing. As pointed out by the American Prosecutors Research Institute in 2015, the procedures followed by a scientist are as follows:

1. Identification the genetic profile of the biological samples (for instance, sperm remains in a rape case) obtained at crime scene;

2. Identification of genetic profile from the suspect or suspects samples;

3. Comparison between these two profiles to get a matching or difference;

4. Calculation of the statistical probability of a random individual having the same genetic profile as the genetic profile obtained from crime scene; and

5. Submission of samples and tests' results to investigation officer, enabling the prosecution to use all related DNA evidence during trial in court. Such information helps the court in determining the offender for the relevant cases.

Indeed, the unique processes of forensic investigation involving DNA profiling, testing and determination have proven that DNA evidence is indeed a reliable form of evidence and proof if tendered in syariah courts' proceedings. While application and tendering of such evidence is currently a rarity, its potential role and application in syariah courts have never been in doubt. As such, the authors respectfully argue that its relevancy, admissibility, reliability and strength should not be questioned (Mohd Munzil et.al, 2015; Azam et.al, 2015).

\section{Adducing and Tendering of DNA Evidence at Syariah Court through Experts}

Expert opinion or known as ra'yu al-khabir refers to a testimony containing an opinion given by someone who is an expert in any field (Ahmah Fathi Bahnasi, 1989; Ramalinggam Rajamanickam, 2017; Ramalinggam Rajamanickam \& Anita Abdul Rahim, 2014). Not only that, the testimonials conferred on scientific, technical or professional matters by qualified and authoritative experts testifying on such matters may be categorized as expert information. The expert's opinion is usually issued by those who have undergone training, specific skills or habits of a person on such matters (Mahmud Saedon, 1996). However, its application in the Syariah court is seen as less efficient than that of the civil court due to its limited provisions. Moreover, syariah cases are not as complex as cases in the civil court.

Procedure of an expert testimony testifying in the court is stated in the case of Wong Chop Saow [1995] MLJ 247. It was decided that "before an expert proceed to testify he shall first state his qualifications (such as academic, professional, experiential, research, writing). The expert should also state whether or not he has testified before in other cases and to what degree has his expert testimony been accepted by the Courts."

The expert witness will then proceed to testify in court in tandem with section 33 (1) and (2) of the states' Syariah Court Evidence Enactments. Section 33 (1) and (2) read as follows:

33. (1) When the Court has to form an opinion upon a point of foreign law or of science or art, or as to identity or genuineness of handwriting or finger impressions or relating to determination of nasab, the opinions upon that point of persons specially skilled in that foreign law, science or art, or in questions as to identity or genuineness of handwriting or finger impressions or relating to determination of nasab, are qarinah.

(2) Such persons are called experts.

However, when there is a discrepancy or conflicting opinions between two experts, both experts' opinions will not be admitted in court and a third expert will be summoned instead to testify in its effort to solve the said issue. Such procedure is seen in section 33 (3) of the states' Syariah Court Evidence Enactments:

33. (3) Two or more experts shall be called to give evidence where possible but if two experts are 
not available, the evidence of one expert is sufficient. If two experts give different opinions a third expert shall be called to give evidence.

Expert opinions may be given in the form of testimony of experts on forensics and scientific methods as well as results and findings of the conducted tests. Section 33 of the Syariah Court Evidence Enactments clearly provides the avenue for those parties to submit views from experts based on the analysis and findings from conducted scientific tests such as the DNA tests. For example, the analysis and findings from a genetic specialist may reveal the truth in the birth and paternal issues of unlawful children. Evidence based on the analysis and findings of the medical expert on injury or death of a victim can resolve a criminal case or corroborate compensation claims for any suffered injury.

In the above instances, there are three aspects of qarinah involved. First of all, when the expert testifies verbally in court regarding the DNA testing and scientific findings, such oral testimony of the expert becomes a qarinah. Secondly, every DNA sample tendered and verified by the expert would also become a qarinah. Thirdly, if the written report of such testing, profiling and finding is tendered in court and its content is verified by the expert, then such report would also qualify as a qarinah.

The following illustrations are given to illustrate the afore-mentioned three types of qarinah. For instance, in a prosecution of a syariah criminal offence of illegal intercourse, a DNA sample, say in the forms of two seminal samples, are tendered as exhibits during trial through the expert witnesses of the examining doctor and the chemist. The reason for such tendering of the said samples is to prove through both experts that there has been a consensual intercourse between the two accused outside legal wedlock. During the trial, the examining doctor verifies that both seminal samples are the ones which are recovered during medical examinations on both male and female accused. The doctor then testifies that the results from both medical examinations on both accused reveal that there is a sign of consensual intercourse on the female accused due to the hymen tear, the lack of abrasion within the inner vagina wall as well as traces of semen found inside the vagina. The doctor also testifies that he performs vaginal swab on the female accused to retrieve samples of semen as well as obtaining seminal sample from the male accused. Meanwhile, the chemist later verifies both seminal samples as actual samples which have been sent to him for DNA testing. He then proceeds to testify regarding the testing, profiling and findings of both seminal samples, concluding that there is almost a $100 \%$ degree of similarities between both seminal samples. During both expert testimonies, written reports from both experts are also tendered (Azam et.al 2015).

First of all, it is clear that both experts are testifying under section 33 of the Syariah Court Evidence Enactments as qarinah and the contents of their oral testimonies which contain testimonies of the testing and findings are also qarinah. This is provided for under section 39 of the enactments that state that whenever the opinion of any living person is qarinah, the ground on which his opinion is based is also qarinah. Secondly, when the seminal samples are tendered and verified by both experts, and both expert findings prove the existence of facts which are relevant to establish identity (namely the relevant facts that there is sexual intercourse between both accused and that such intercourse is consensual) as provided under section 9, this clearly means that both seminal samples are tendered as qarinah via section 9. Last but not least, when written reports of the expert findings are tendered through, and verified by both experts during trial, these written reports are regarded as documentary evidence under section 48 of the enactment. Similarly, when the contents of these reports contain findings which establishes the relevant fact that there is a consensual sexual intercourse between both accused, then the content of both reports become a qarinah too.

It must be observed that the Act does not define the expertise of a person based on religion or degree of credibility. What matters is that the person must be an expert in his field. Thus, a nonMuslim expert can give his opinion in the syariah court. The opinions of an expert, muslim or nonmuslim, are simultaneously considered qarinah and bayyinah as decribed under section 83 (2) of the states' syariah court evidence enactments. What matters most is that the test is conducted transparently and with utmost integrity, and also the fact that the chain of evidence is unscathed 
from the day the samples are collected right until the day it is presented and adduced in court.

\section{Admissibility DNA Evidence in Malaysian Syariah Courts: Problems and Recommendations}

The authors identify lacunas and gaps in the current provisions in the Malaysian Syariah Court Enactments and Syariah Criminal Procedure Enactments regarding application of principles on qarinah and DNA evidence.

While there are provisions in the states' Syariah Court Evidence Enactments regarding qarinah, it is also observed that there is a gap in its definition. First of all, we hereby suggest that the definition of qarinah under section 3 should be further clarified and refined to include 'any fact or evidence which surround the circumstance of a case.' We also suggest that the defining provision of qarinah should also include different types of qarinah which should include scientific evidence. It follows that such an amended definition of qarinah should then be followed with a clarification of the status of DNA and other forms of scientific evidence as instances of evidence which may fall under the ambit of a qarinah. Most importantly, the authors also point out that there is no provision in the Syariah Court Evidence Enactments which clarifies what amount to a strong qarinah. In other words, there is an urgent need for the new provision on qarinah to illustrate and include corroborative qarinah as part of the qarinah strength.

The authors also reiterate the importance of further enhancements on several qarinah-related provisions. For instance, there should be new provisions in forms of illustrations or explainations on important evidential principles of chain of custody and chain of evidence. This is because both principles form important evidential aspects of qarinah admissibility and strength. Simultaneously, since there is no provision available under the Malaysian Syariah Criminal Procedure Enactments to empower an investigating officer to bring a suspect under interrogation to hospital for a medical examination, the authors therefore argue that new provisions giving such empowerment should be inserted in the said enactment. Lacuna on such aspect would hamper the process of samples' collection during investigation by syariah enforcement officers.

The authors respectfully argue and suggest that all procedures relating to adducing and tendering of such DNA evidence via expert witnesses as well as via exhibits should be refined further. The best way to do this is to insert new syariah legal provisions in related enactments. The proposed new provisions under the states' Syariah Court Evidence Enactments which defines qarinah should also include an explanation stating that all scientific evidence should be adduced in accordance with due process recognised by law. Consequentially, it follows that new standard operating procedures should be enacted by the Malaysian Syariah Judiciary Department, locally known as 'Jabatan Kehakiman Syariah Malaysia (JKSM)' in streamlining and guiding the overall process of cumulating and adducing this scientific evidence. For instance, the standard operating procedure for adducing an expert witness in court should be enacted, covering important issues such as how to establish the expertise of an expert witness, when the court allows the calling of a second expert witness and how to address the issues of conflicting analysis by two different experts. On another note, the standard operating procedure for recovery of DNA sample during investigation as well as the standard operating procedure for adducing physical exhibits in court should simultaneously be enacted to ensure transparency, reliability and authenticity. In addition, both standard operating procedures would ensure maintenance of chain of custody as well as chain of evidence of each physical evidence presented in forms of exhibits during trials (Azam, 2012).

\section{Concluding Remarks}

In conclusion, the authors respectfully hope that the above analysis, findings and recommendations should be taken note of and acted upon. We firmly believe on the importance of acting on every recommendation made in this article on Malaysia's current Syariah Court Evidence Enactments and Syariah Criminal Procedures Enactments.

We believe that should the relevant authorities do amend the related provision as recommended, it would surely be in tandem with our on-going effort and struggle to increase the 
jurisdiction of the syariah courts in Malaysia. Surely an increased syariah court jurisdiction would warrant a more complete and refined evidential and procedural legal provisions in the enactments.

\section{Acknowledgement}

This research is funded by Universiti Kebangsaan Malaysia (UKM) through research grant i.e. GGPM-2017-019.

\section{References}

Abd al-Karim Zaydan. 1998. Nizam al-Qada' fi al-Syariah al-Islamuyyah. Beirut: Muassasah al-Risalah.

Ahmad Azam Mohd Shariff. 2012. Prosedur Siasatan dan Pendakwaan Kes Jenayah Syariah: Analisis ke atas Perundangan Jenayah Syariah di Malaysia. Doctor of Philosophy (Law) Thesis Faculty of Law, Universiti Kebangsaan Malaysia. UKM-Bangi.

Ahmad Azam Mohd Shariff, Mazupi Abdul Rahman, Ramalinggam Rajamanickam. 2015. Admissibility of DNA Evidence in Malaysian Syariah Courts: Setting the Right Course. CLJ-SHR Shariah Reports [2015] i-xxvi

Ahmad Fathi Bahnasi. 1989. Nazariyyat al-Ithbat fi al Figh al-Jana`i al-Islami. Qahirah: Dar al-Syuruq.

Akhzailina Md Akhir. 2000. Keterangan DNA: Kepentingan, Keperluan dan Kaedah Pemakaian di Malaysia. Latihan IImiah, Fakulti Undang-Undang Universiti Malaya.

American Prosecutors Research Institute. 2015. Forensic DNA Fundamentals. http://www.ndaa.org: http://www.ndaa.org/pdf/forensic_dna_fundamentals.pdf.

Anwarul Yaqin. 2007. Legal Research Writing. Malaysia: LexisNexis.

Anwarullah. 1999. Evidence by Expert (Experts' Opinion) in Principles of Evidence in Islam. Kuala Lumpur: A. S. Noordeen Press.

Mahmud Saedon A. Othman. 1996. An Introduction to Islamic Law of Evidence. Shah Alam: HIZBI.

Mahmud Saedon A. Othman. 2003. Undang-undang Keterangan Islam. Kuala Lumpur: Dewan Bahasa dan Pustaka.

Mohamad Ridzuan bin Zainudin. 2012. Pembuktian DNA di Mahkamah Syariah. Majlis Agama Islam Selangor: MAIS News.

Mohd Munzil Muhamad, Ahmad Azam Mohd Shariff, Ramalinggam Rajamanickam, Mazupi Abdul Rahman, Md. Anowar Zahid, Noorfajri Ismail. 2015. Qarinah: Admissibility of Circumstantial Evidence in Hudud and Qisas Cases. Mediterranean Journal of Social Sciences, Vol. 6 No. 2, 141-150.

National Institute of Health. 2016. National Human Genome Research Institute. http://www.genome.gov:http://www.genome.gov/25520880

Phillips et.al. 1989. Forensic Science and Expert Witnes. Sydney: The Law Book Co. Ltd.

Ramalinggam Rajamanickam. 2017. Scope of Section 45 of Evidence Act 1950: The Need For Revision 2017 Special Issue. UKM Bangi: JUUM.

Ramalinggam Rajamanickam \& Anita Abdul Rahim. 2014. The Position of Psychological Expert Evidence under the Malaysian Evidence Act 1950. Mediterranean Journal of Social Sciences, [S.I.], Vol. 5, No. 14, July 2014.

Ramalinggam Rajamanickam et al. 2015. The Position of Similar Fact Evidence in Malaysia. Mediterranean Journal of Social Sciences, [S.I.], Vol. 6, No. 4, July 2015.

Ramalinggam Ramalinggam et al. 2019. The Assessment of Expert Evidence on DNA in Malaysia. Academic Journal of Interdisciplinary Studies, [S.I.], Vol. 8, No. 2, July 2019.

Rohani Abdul Rahim. 2002. Metodologi Penyelidikan Undang-undang: Satu Tinjauan Kepada Kajian SosioPerundangan. Seminar Kemantapan Akademik UKM Bangi: UKM.

Wahbah Zuhaily. 1989. Al-Fiqh Islami wa Adillatuhu. Vol. 6. Damsyik: Dar al-Fikr.

Mawarni Bt. Abdul Rahman. 2015. Applicability of DNA Testing as Evidence in Malaysia. Science Officer (C41), Department of Chemistry Malaysia, Penang, (Northern Branch). Interviewed on July 2015.

Pendakwa Syarie Negeri Sabah v Rosli bin Abdul Japar (2007)23/2 JH 237.

Wong Chop Saow v Pendakwaraya (1995) MLJ 247

Ahmad Najib Aris v PP (2007) 2CLJ229 